\title{
COVID-19 pandemic through the lens of person-situation interaction
}

\author{
Erita Narhetali \\ Fakultas Psikologi, Universitas Indonesia, Depok, Indonesia \\ Faculty of Economics Sciences, University of Warsaw, Poland
}

\begin{abstract}
This paper aims to describe how emotions, risk perceptions, and social norms shape their protective behavior under uncertainty time of the COVID-19 pandemic. Protective behavior means all individual efforts to comply with the pandemic measures: staying at home, hand washing, physical distancing, and wearing masks. Borrowing insight from the personsituation theory by Kurt Lewin, I try to entangle the interaction between personal and situational factors lingered within the pandemic environment that leads to our particular behavioral response. Following this, I discussed how people can comply with the measures and policies being enacted.
\end{abstract}

Keywords: COVID-19, person-situation theory, emotions, risk perception, social norms

\begin{abstract}
Tujuan dari tulisan ini adalah untuk menggambarkan bagaimana emosi, persepsi risiko dan norma sosial membentuk perilaku sehat di masa yang penuh ketidak-pastian seperti pandemi COVID-19 ini. Perilaku sehat dalam hal ini berarti semua upaya individu untuk mematuhi langkah-langkah mitigasi pandemi: tinggal/berdiam diri di rumah, mencuci tangan, menjaga jarak fisik, dan mengenakan masker. Mengambil inspirasi dari person-situation theory dari Kurt Lewin, saya mencoba mengurai interaksi antara faktor personal dan situational dalam lingkungan pandemi serta bagaimana proses interaksi tersebut membentuk respon perilaku sehat manusia. Berangkat dari pemahaman ini, kami juga mendiskusikan bagaimana masyarakat bisa mematuhi kebijakan dan peraturan yang diberlakukan.
\end{abstract}

Kata Kunci: COVID-19, person-situation theory, emosi, persepsi risiko, norma sosial

\section{Introduction}

By the time this article is written, COVID-19 has infected almost 10 million people in the world and halting world economies by about $5 \%$ on average. In a behavioral sense, a pandemic may be best described as a whole human effort to avoid risky behavior under circumstances full of uncertainty and negative emotions. The keynote is to prevent the virus from spreading and being transmitted. Hence, this is collective health that we concern about, not particular personal health. The previous study explained the role of working memory as an important individual differences predictor for social distancing behavior, in which limited capacity of working memory was shown to predict its lesser capability in counting the benefit over the cost of social distancing effort and vice versa (Xie, et al., 2020). On the other hand, other studies pinpoint the contribution of social identity in underplay risk perception and

Submitted: April 27th 2020

Accepted: July $3^{\text {rd }}, 2020$ therefore, increase riskier health-related behavior in this pandemic time (Cruwys, et al., 2020). I argue that taking a more interactive view between individual differences and the nested environment where they relate to, will give a better understanding of the dynamic between factors that we expect to shape the way protective behavior being performed during the pandemic time. Departing from this perspective, I use the framework of field theory from Karl Lewin - that behavior is a result of constant tension between person and the environment (Lewin, 1939)—to discuss the interaction between the person within the pandemic environment. Behavioral scientists concern about the way human cognitive and emotion interrelates with the way people making decisions and perform a behavior. However, this paper will focus on the emotion and risk perception aspects as the main drivers of individual differences, and social norms for the interaction with the environment that is considered relevant for this paper.

\footnotetext{
* Fakutas Psikologi, Universitas Indonesia Jl. Lkr. Kampus Raya Jl. Mawar, Kota Depok, Jawa Barat E-mail: e.narhetali@uw.edu.pl
} 


\section{The person}

Lazarus (1991) defined emotions as "organized cognitive-motivational-relational configurations whose status changes with changes in the person-environment relationship as this is perceived and evaluated". Further, he explained that we use emotions as basic cues for our information system to make sense of, and respond to, circumstances that people encounter. Many evidences supporting the argument that emotions and cognition is interrelated (see e.g. Frijda, Kuipers, \& Schure, 1989; Izard, 1993; Lazarus, 1991; Nabi, 2003). Needless to say, emotions play a significant role in shaping our behavior, such as how we respond to the public communication in crisis (Jin, Pang, \& Cameron, 2012) or picking up response in a casual social interaction (Sznycer \& Lukaszewski, 2019).

This pandemic is identified with the major flow of negative emotions like fear, anxiety, and sadness (e.g. Bults, et al., 2011; Hossain, Sultana, \& Purohit, 2020; Kim \& Niederdeppe, 2013; and Ornell, Schuch, Sordi, \& Kessler, 2020). It is, however, important to note that although fear and anxiety are closely related as an emotional phenomenon, many studies showed that they are different. Understanding the differences is crucial as it will need different types of intervention to be in place for each of them in the most efficient way.

By definition, fear is an adaptive animal defense mechanism that is fundamental for survival and involves several biological processes of preparation for a response to potentially threatening events (Garcia, 2017). Anxiety is often a "pre-stimulus" conducted as anticipation toward a threatening stimulus, while fear is "poststimulus" elicited by an already defined fear stimulus (Öhman, 2008). Epstein (1972) put it in a more behavioral term; fear is related to coping behavior like escape and avoidance. When coping attempts fail because maybe the situation is out of control, then fear is turned into anxiety. However, fear leads to an increased desire to affiliate, while anxiety is to the opposite (Sarnoff \& Zimbardo, 1961). In addition, worry is considered to arise from cognitive processes involved in anxiety, that serve to maintain high levels of vigilance for personal danger (Borkovec, Ray, \& Stöber, 1998). Worry is the cognitive dimension of anxiety, but both are commonly treated as the affective dimension of risk (Liao, Cowling, Lam, Ng, \& Fielding, 2014).

In normal times, we are often told that human behaves mostly in an irrational manner and from time to time needs to be "nudged" to comply with social norms. The nudge is needed due to the cognitive biases that cover the human mind out of the ability to produce an effective decision, at least according to the rational thinking regime. Negative emotions, especially affect the way people determine risk through a bias called "affect aversion" - a tendency to rely more on risk as intuition rather than as a tool to manage risk (Fischhoff, Slovic, Lichtenstein, Read, \& Combs. 1978; Slovic \& Peters, 2006). Yet, affective aversion is not always a bad thing. This type of bias may save the life of human beings when it is exercised using a proper consideration of timing and proportion. In fact, experts in the areas of risk and probabilities actually suggest that during the pandemic time, particularly where uncertainty is on the highest level due to the absence of the vaccine, people should be anxious rather than relaxed (Taleb \& Norman, 2020). He explained further that:

"... if she or he does not panic and act in an ultra-conservative manner, they will contribute to the spread of the virus and it will become a severe source of systemic harm. Hence one must "panic" individually (i.e., produce what seems to an exaggerated response) in order to avoid systemic problems, even where the immediate individual payoff does not appear to warrant it. This happens when the systemic risk is small to the individual but common to all, while an individual's other idiosyncratic risks dominate her or his own life."

During the pandemic time, fear increases anxiety and stress levels in healthy individuals (Ornell, et al., 2020) and therefore lead people to avoid risky behavior (Lerner \& Keltner, 2001; Maner, et al., 2007). Meanwhile, anxiety is proven to be a consistent predictor for protective behavior during pandemic (Bults, et al., 2011; Jin, et al., 2012; Liao, et al., 2014; Maner, et al., 2007; Rubin, Amlôt, Page, \& Wessely, 2009). A study on the pandemic of Swine Flu, as reported by Goodwin, Gaines, Myers, and Neto (2011) showed that the initial emotional concerns-like worrying about being infected-would be a significant predictor of individual behavioral responses to the pandemic threat. This result is in line with a current survey in 41 countries from March $17^{\text {th }}$ to April $1^{\text {st }}, 2020$, which found that perceived worry and changes of behavior as a response to the new epidemic outbreak were significantly higher among those who expressed concern and perceived increased susceptibility to the COVID19 (Limcaoco, Mateos, Matías, \& Roncero, 2020).

In the case of respiratory infection diseases such as COVID-19, the pathogen is invisible for the naked eyes. It is impossible to see how it is transmitted or whether our distancing effort 
really makes an impact on the decline of the virus spreading. This uncertainty feeds more cognitive biases to the human mind that works in a contraproductive manner. Some people may suffer from "unrealistic" optimism that the disease will unlikely befall to themselves as has been found in the early phase of the outbreak in Europe (Raude, et al., 2020). This optimistic bias phenomenon is also to be found during similar unprecedented events such as Katrina and Rita hurricane in the US (Trumbo, Meyer, Marlatt, Peek, \& Morissey, 2014), and the prevalence of the chikungunya epidemic among French Guinan in 2015 (Raude, McColl, Flamand, \& Apostolidis, 2019).

This phenomenon isn't merely found among the laypeople alone; as this over-confidence biases (such as optimism bias or normalcy bias) are also among the most common cognitive biases perpetrated by the government during this pandemic time (Kuper-Smith, Dopperlhofer, Oganian, Rosenblau, \& Korn, 2020). This conservative judgement that leads into an already too-late installation or overly fast dispel of the measures often came under the basis of economic arguments rather than epidemiological. Now, it can be said that the differences in the pattern of the outbreak across countries are related to the pattern of conservative versus aggressive measures taken by the governments. A study conducted by disease control experts in China suggested that the conservative judgment about the epidemic risk was rooted to the habitual thinking of low probability with uncertain progression, and the fear of the impact of the decision both when the opinion is accurate or false (Qi, Du, Liu, Zhao, \& Dong, 2020).

Nonetheless, for some individuals, worries about contracting virus may become excessive, leading to inordinate distress and anxiety, as well as avoidance behaviors that significantly impair functioning (Nicholas, 2020), boredom (Martarelli \& Wolff, 2020), or post-traumatic stress symptoms, confusion, and anger as an impact of being in quarantine (Brooks, et al., 2020). This highlights an important distinction: a certain amount of pandemic-related fear and anxiety can be adaptive such that it focuses attention and motivates appropriate protective behavior. However, one should be aware that the interaction of the huge flow of negative emotions and cognitive biases in thinking may pour inaccuracy and mislead our decision.

Can we expect individuals to be able to react to their fear and anxiety in order to produce protective behaviors? The answer is yes, surely, as long as we know how to control such reactions. Unfortunately, not all of our behavior can be fully under our control. According to Freudian psychoanalytic theory, humans develop an internal mechanism inside the human psyche that operates response to unpleasant stimuli. This mechanism is named defense mechanism function and is driven by an unconscious process (Erdelyi, 2001). Freud believed that human beings are pleasure seekers, and sufferings are to be avoided whatsoever. This is expressed as a refusal to accept the state of emergency found during this pandemic time. This leads to the manifestation of the defense mechanisms of denial and projection (Freud, 1937). People are showing anger and hatred towards specific ethnic groups for the spread of the epidemic. Roy and Sinha (2020) suggests in their work that the projection and denial may manifest itself in the way people blaming the Chinese Government and the WHO for the pandemic outbreak, along with the hateful messages prevalent on social media.

In relation to this, however, I would like to bring our attention to the concept of the so-called behavioral immune system (Schaller, 2006), rooted from the perspective of evolutionary psychology. Originated from a basic mammalian defense system, this is a protection system from a perceived external threat which allows individuals to detect the potential presence of parasites in the objects and individuals around them, and to engage in behaviors that prevent contact with those objects and individuals (Kurzban \& Leary, 2001; Park, et al., 2003; Schaller, et al., 2003).

It is suggested that emotions like fear and disgust play a very crucial role in the works of the behavioral immune system through behavioral avoidance, particularly disgust (Schaller \& Duncan, 2007). This occurs by inducing avoidance, a rejection toward the object that shows symptoms of physical illness (Schaller \& Duncan, 2007). It got worse by the spread of misinformation and conspiracy theories that spur the hatred at an outrageous level (Pennycook, et al., 2020).

Another strong negative emotion that is prevalent in this pandemic time is sadness. People suffer from the loss of their loved ones, feeling pain from losing proximity from their significant others, or being hurt by losing their job due to this economic pandemic-related crisis. A normal reaction to these loss experiences is grief. Unfortunately, grief is difficult to-beexpressed and recognized by the person who experiences this feeling. This makes it harder to be regulated with rational thinking. Kubler-Ross and Kessler (2004) argued that grief is often translated into five stages of loss, which they put in an acronym DABDA: Denial, Anger, Bargaining, Depression, and Acceptance. These five stages of loss can explain (although not strictly in a sequential fashion) the observed behavior as the outbreak spread all around the world. Denial is 
the most common response during the initial stage.

When the government starts to impose social distancing measures on various levels, Anger starts to take place in many forms. Denial is also seen frequently as various forms of behavior aim at violating the measures. Bargaining and Depression come afterward when the situation shows itself in its full reality. This is eventually followed by Acceptance, as people start to work together to overcome what is left by the pandemic (Chen, et al., 2020; Roy \& Sinha, 2020).

\section{The person within the environment}

People do not make their decisions in isolation. Ironically, it is true even in a pandemic time where distancing and isolating have been the major narratives that people encounter. In almost every social interaction, human behavior is determined by what they think the other person will do. Most likely, it will reflect their expectation of what other people will do; to be selfish or selfless. According to Kelley and Stahelski (1970), this is the situation where a gap of understanding-which will lead to failure in attributing other's behavior is most likely to happen. This phenomenon is described as social norms. By definition, social norms are behavioral rules supported by a combination of empirical and normative expectations (Bicchieri, 2006). Similar with Cialdini (2003), these two expectations lead to two different types of norms; the injunctive norms are the normative expectations which refers to perceptions of which behaviors typically approved or disapproved by the society; and the descriptive norms that involve empirical expectations which refers perception on behaviors typically performed by the society. Both types of these norms may motivate human action as people tend to do what is socially approved as well as what is popular. The key question is how to induce the right norms during this pandemic as the best strategy for prevention measures.

Current research in group psychology during the time of crises emphasis the increase in sense of togetherness induced by shared identity z Haslam \& Reicher, 2006; Alfadhli, Güler, Cakal, \& Drury, 2019). This sense of togetherness may lead to increase support and cooperation among society members and at the same time will endorse happiness to grow. This shall perfectly balance our mental health to face difficulties during the pandemic time. But again, how easy it is to gain cooperation during the pandemic time? Or, what is the balance (if any) between the incentive to cooperate and not to cooperate (with the pandemic measures)? Unfortunately, given the whole projection of the weakness that people may suffer during this pandemic, the cooperative ability is another battleground for protective behavior.

The key aspects of the pandemic measures during the phase when no vaccine available are centered around the social distancing measures and all its derivatives strategies (such as physical distancing, restriction, shut down, and lockdown). But in any scenario, there will always some spaces open for basic needs essentials sector to operate. This means that there is a room (e.g. a quiet street, fresh air, sunny day, and a cozy ride by using mass transportation with only half capacity used), available outside to take advantage of. This unravels the ground for the need of a highly functional collective society that willing to sacrifice their personal freedom to gain higher collective health. The trade-offs are as follows. Consider two types of person: The Selfish and the Selfless. The Selfish will surely try to open the window to get this opportunity, as much as possible for themselves. On the contrary, The Selfless might think that those windows of opportunity should be kept open for those who might need it. For our case, the Selfless type is an ideal prototype to produce such adaptive behavior so we will leave them. However, a closer look at The Selfish type may reveal something more. They may not be in their best psychological state after being in quarantine for some time (Brooks, et al., 2020), and they may also suffer from optimism bias that they would not get infected (Kuper-Smith, et al., 2020), while also showing lack of trust toward the government's measure (Fetzer, et al., 2020). On top of that, they may not live in an isolation: they may be walking around outside, regardless of the adaptive behavior message are being circled around by the government or others (Berkowitz, 2005; Dickie, et al., 2017). Considering all those possibilities, there is a strong likelihood that such type of people will choose to continue the selfish act and taking benefit from the small portion of the collective resources available during this pandemic.

Now, let us also consider that there are other Selfish types of people in the world and they are inevitable will be seeing and mimicked each other's behavior as eventually more and more people taking advantage of the resources. This is how the conformity occurs and may end up in a phenomenon famously known as the tragedy of the commons-a common pattern in public good situations.

However, again, most evolutionary psychologists believe that conformity is somewhat driven by disease avoidance behavior. Pathogens and parasites may serve as signifiers for different behavioral immune adaptations across human beings. The behavioral immune system works by 
"warding off potential disease connoting cues" (Schaller \& Duncan, 2007) because the pathogens are invisible by naked eyes. The ward is stronger when the cues are carried by outgroup members because the human physical immune system is particularly vulnerable to outgroup germs in comparison to those shared by people living together (Fincher, Thornhill, Murray, \& Schaller, 2008). Wu and Chang (2012) further tested the association between pathogen threat and conformity. They revealed that perceived vulnerability to disease uniquely predicted conformity tendencies. They also found that participants primed by pathogen threat conformed more to majority views when evaluating abstract art drawings and rated themselves as more conforming to a questionnaire. The human behavioral immune system works by responding to abnormal appearances and deviant behaviors for this reason. This is possible because even though pathogen is invisible, the effect is often visible.

Nonetheless, when this interacts with conspiracy theories, misinformation, or fake news, it is very likely too that such a tendency will transform into prejudice and discrimination toward specific outgroups as we have discussed earlier. In our case, this result can be interpreted as a slippery slope between the conformity that prevails to prevent the spread of the virus by spreading the common norms of adaptive behavior (e.g., complying to the pandemic measures), and the conformity that works by discriminating abnormal stimulus and projecting this abnormallity via the lens of morphology and deviant behavior as an outgroup avoidance (e.g., by being discriminative and prejudice). This possibility of these two types of responses has been recognized by $\mathrm{Wu}$ and Chang (2012) as an implication of their study.

Additionally, we should also consider that in the case of this COVID-19 pandemic, not all of the effects of the pathogen can be visible for naked eyes. Many experts suggested that numbers of those with no symptoms may represent the majority of the positive case. This may turn our slippery slope even steeper as the outgroup avoidance becomes more salient due to the increased anxiety level. It can also be an indifferent slope because people might be unable to see the differences for what we recall as availability bias and anchor bias (e.g. media hypes on charting death number and infected cases rather than positive versus negative ratio resulted from the testing). The solution for this tragedy is social cooperation, yet, social cooperation is easier to provide, but harder to maintain because people at one time will learn that cheating may benefit them more than cooperate (Gächter, et al., 2017).

\section{Dynamics of social norms: How people can comply with the measures}

During this pandemic, there will be at least two crucial times in developing social norms: (1) the beginning of the pandemic as the society enters the lockdown; and (2) the transition period where the lockdown is to be lifted. According to Bicchieri (2017), there are two important requirements for norms to be established: enough people who know that the shared norms exists and comply with such norm. This may reflect the problem with the COVID-19 mitigation measures: there are not "enough" people who know about these norms and willing to comply with these norms ever since the beginning of the pandemic. First, in the early period of the pandemic, the stay-athome call was being launched while most likely many people do not entirely understand about the call. Establishing a norm of stay-at-home will be challenging both through empirical expectation as people observe that most of them are still not complying with this norm. Normative expectation also not easy to be imposed since this is a new norm and not so empirically tested (the pathogen is invisible, harder to believe in something we cannot feel or see through directly our own senses).

What should be done? According to this theory of social norms, as well as the available empirical data as we see currently in the world, the use of government policies as early as possible is the most possible answer. Countries that successfully flattening their curve are those who put the strict restrictions in place along with punishment for violating the rules (Johannes \& Jessica, 2020). Under this condition, both empiric and normative expectations will be more easily formed and aligned in shaping the solid preference of compliance to the stay-at-home call.

Second, is the period of entering to relaxing phases after applying the lockdown restriction. This might seem easy, but in fact, this part is even harder compared to the first. Prior to lockdown flattening the curve was the main focus of all the non-pharmaceutical interventions. After the decision of lockdown had been made, the timing to consider to ease or lifting the restriction becomes more policy matter rather than an epidemiological one. The restriction could not be maintained indefinitely due to the economic and social costs. On the other hand, lifting measures too early may also causing the return of the exponential growth (or some people may say, just spikes) of the infected cases.

Yet, the government's ability to provide clear protocols related to the stay-at-home measures (e.g. who can use the public transportations, when, how many, where, etc.) is more 
crucial than ever this time. The details of the protocol are even more important at this stage because during this transition period people can see more people go out than before, without being able to tell the difference whether the reason for this-seems to be an incompliance act toward the call for the stay-at-home call-is legit or not. In other words, both normative expectation empirical expectation will be poorly aligned. Even worse, bad norms can grow and survive if there is no way to openly communicated what expectations should be followed. Overall, these ambivalent situations will be a fertile ground for the growth of preference to not comply with pandemic mitigation measures.

\section{Conclusion}

The importance of emotions in crisis management during the pandemic time had been highlighted by Kim and Niederdeppe (2013). However, it is also important to note that the intention for protection does not always translate into consequential behavior in pandemic times (Williams, Rasmussen, Kleczkowski, Maharaj, \& Cairns, 2015). Other factors such as risk preference and social interactions may contribute more or less equally. The importance of "situation" in inflicting impact on human emotions and behavior, and that impact of the situation, may differ on every individual is highlighted. Choosing whether or not to comply with pandemic measures urged by the government is not a simple task for most people, especially when emotions and biases affect decisions: individuals must face a constant dilemma between getting the gain from not complying with the rule and suffering the cost associated to compliance instead. Further, the dynamic of person and situation orchestrated by social norms may push the equilibrium of that dilemma toward the bad norms that lead to selfish gain rather than collective gain. Apart from clear and strong government measures, the solutions perhaps lie in enforcing the good social norms, both the descriptive and injunctive norms, in the strongest way it possibly be.

\section{References}

Alfadhli, K., Güler, M., Cakal, H., \& Drury, J. (2019). The role of emergent shared identity in psychosocial support among refugees of conflict in developing countries. International Review of Social Psychology, 32(1), $1-16$. https://doi.org/10.5334/irsp.176

Berkowitz, A. (2005). An overview of the social orms approach. Changing the Culture of College Drinking: A Socially Situated
Prevention Campaign, August, 1-29. http://alanberkowitz.com/articles/social norms approach-short.pdf

Bicchieri, C. (2017). Norms in the wild: How to Diagnose, Measure, and Change Social Norms. Oxford University Press.

Borkovec, T. D., Ray, W. J., \& Stöber, J. (1998). Worry: A cognitive phenomenon intimately linked to affective, physiological, and interpersonal behavioral processes. Cognitive Therapy and Research, 22(6), 561-576. https://doi.org/10.1023/A:10187900034 16

Brooks, S. K., Webster, R. K., Smith, L. E., Woodland, L., Wessely, S., Greenberg, N., \& Rubin, G. J. (2020). The psychological impact of quarantine and how to reduce it: rapid review of the evidence. The Lancet, 395(10227), 912-920. https://doi.org/10.1016/S01406736(20)30460-8

Bults, M., Beaujean, D. J. M. A., De Zwart, O., Kok, G., Van Empelen, P., Van Steenbergen, J. E., Richardus, J. H., \& Voeten, H. A. C. M. (2011). Perceived risk, anxiety, and behavioural responses of the general public during the early phase of the Influenza A (H1N1) pandemic in the Netherlands: Results of three consecutive online surveys. $B M C$ Public Health, 11, 1-13. https://doi.org/10.1186/1471-2458-11-2

Chen, Q., Liang, M., Li, Y., Guo, J., Fei, D., Wang, L., He, L., Sheng, C., Cai, Y., Li, X., Wang, J., \& Zhang, Z. (2020). Mental health care for medical staff in China during the COVID-19. Lancet Psychiatry, 7(April), 19-20. https://doi.org/10.1016/S22150366(20)30078-X

Cialdini, R. B. (2003). Crafting normative messages to protect the environment. Current Directions in Psychological Science, 12(4), 105-109. https://doi.org/10.1111/14678721.01242

Cruwys, T., Stevens, M., \& Greenaway, K. H. (2020). A social identity perspective on COVID-19: Health risk is affected by shared group membership. British Journal of Social Psychology, 584-593. https://doi.org/10.1111/bjso.12391

Dickie, R., Rasmussen, S., Cain, R., Williams, L., \& MacKay, W. (2017). The effects of perceived social norms on handwashing behaviour in students Rachel. Psychology, Health and Medicine.

Epstein, S. (1972). The Nature of Anxiety with Emphasis upon Its Relationship to Expectancy. In Anxiety: Current Trends in 
Theory and Research (pp. 3-19). https://doi.org/10.1016/b978-0-12657401-2.50008-3

Erdelyi, M. H. (2001). Defense processes can be conscious or unconscious. The American Psychologist, 56(9), 761-762. https://doi.org/10.1037/0003066X.56.9.761

Fetzer, T., Witte, M., Hensel, L., Jachimowicz, J. M., Haushofer, J., Ivchenko, A., Caria, S., Reutskaja, E., Roth, C., Fiorin, S., Gomez, M., Kraft-todd, G., Goetz, F. M., \& Yoeli, E. (2020). Global Behaviors and Perceptions in the COVID-19 Pandemic. PsyArXiv [Working Paper].

Fincher, C. L., Thornhill, R., Murray, D. R., \& Schaller, M. (2008). Pathogen prevalence predicts human cross-cultural variability in individualism/collectivism. Proceedings of the Royal Society B: Biological Sciences, 275(1640), 1279-1285. https://doi.org/10.1098/rspb.2008.0094

Fischhoff, B., Slovic, P., Lichtenstein, S., Read, S., \& Combs, B. (1978). How safe is safe enough? A psychometric study of attitudes towards technological risks and benefits. Policy Sciences, 9(2), 127-152. https://doi.org/10.1007/BF00143739

Frijda, N. H., Kuipers, P., \& Schure, E. (1989). Frijda_1989_Emotions_Appraisals_Action_ Tendencies. Journal of Personality \& Social Psychology, 57(2).

Gächter, S., Kölle, F., \& Quercia, S. (2017). Reciprocity and the tragedies of maintaining and providing the commons. Nature Human Behaviour, 1(9), 650-656. https://doi.org/10.1038/s41562-0170191-5

Garcia, R. (2017). Neurobiology of fear and specific phobias. Learning and Memory, 462-472. https://doi.org/10.1101/lm.044115.116.2 4

Goodwin, R., Gaines, S. O., Myers, L., \& Neto, F. (2011). Initial psychological responses to swine flu. International Journal of Behavioral Medicine, 18(2), 88-92. https://doi.org/10.1007/s12529-0109083-z

Haslam, S. A., \& Reicher, S. (2006). Stressing the group: Social identity and the unfolding dynamics of responses to stress. Journal of Applied Psychology, 91(5), 1037-1052. https://doi.org/10.1037/00219010.91.5.1037

Hossain, M. M., Sultana, A., \& Purohit, N. (2020). Mental Health Outcomes of Quarantine and Isolation for Infection Prevention: A Systematic Umbrella Review of the Global
Evidence. SSRN Electronic Journal, 1-27. https://doi.org/10.2139/ssrn.3561265

Izard, C. E. (1993). Four systems for emotion activation: Cognitive and noncognitive processes. Psychological Review, 100(1), 68-90. https://doi.org/10.1037/0033295X.100.1.68

Jin, Y., Pang, A., \& Cameron, G. T. (2012). Toward a Publics-Driven, Emotion-Based Conceptualization in Crisis Communication: Unearthing Dominant Emotions in Multi-Staged Testing of the Integrated Crisis Mapping (ICM) Model. Journal of Public Relations Research, 24(3), 266-298.

https://doi.org/10.1080/1062726X.2012. 676747

Johannes, H., \& Jessica, M. (2020). Which interventions work best in a pandemic? Science Galley, 1-11. https://www.princeton.edu/haushofer/pu blications/Haushofer_Metcalf_Corona_202 $0 . p d f$

Kelley, H. H., \& Stahelski, A. J. (1970). Social Interaction Basis of Cooperators' and Competitiors' beliefs about others. Joournal of Personality and Social Psychology, 16(1), 66-91.

Kim, H. K., \& Niederdeppe, J. (2013). The Role of Emotional Response during an H1N1 Influenza Pandemic on a College Campus. Journal of Public Relations Research, 25(1), 30-50. https://doi.org/10.1080/1062726X.2013. 739100

Kubler-Ross, E., \& Kessler, D. (2004). On Grief and Griving: Finding the meaning of grief through the five stages of loss.

Kuper-Smith, B. J., Doppelhofer, L., Oganian, Y., Rosenblau, G., \& Korn, C. W. (2020). Optimistic beliefs about the personal impact of COVID-19. PsyArXiv, 1-4. https://psyarxiv.com/epcyb/

Kurzban, R., \& Leary, M. R. (2001). Evolutionary Origins of Stigmatization: The Functions of Social Exclusion. Psychological Bulletin, 127(2), 187-208. https://doi.org/10.1037/00332909.127.2.187

Lazarus, R. S. (1991). Cognition and motivation in emotion. American Psychologist, 46(4), 352-367. https://doi.org/10.1037/0003066X.46.4.352

Lerner, J. S., \& Keltner, D. (2001). Fear, anger, and risk. Journal of Personality and Social Psychology, 81(1), 146-159. https://doi.org/10.1037/00223514.81.1.146

Lewin, K. (1939). Field theory and experiment in 
social psychology: concepts and methods. American Journal of Sociology 44, No. 6 (May, 1939): 868-896., 6(May), 868-896. https://doi.org/10.1037/10269-020

Liao, Q., Cowling, B. J., Lam, W. W. T., Ng, D. M. W., \& Fielding, R. (2014). Anxiety, worry and cognitive risk estimate in relation to protective behaviors during the 2009 influenza A/H1N1 pandemic in Hong Kong: Ten cross-sectional surveys. BMC Infectious Diseases, 14(1), 1-11. https://doi.org/10.1186/1471-2334-14169

Limcaoco, R. S. G., Mateos, E. M., Matías, J. F., \& Roncero, C. (2020). Anxiety, worry and perceived stress in the world due to the Introduction : MedRxiv, March.

Maner, J. K., Richey, J. A., Cromer, K., Mallott, M., Lejuez, C. W., Joiner, T. E., \& Schmidt, N. B. (2007). Dispositional anxiety and riskavoidant decision-making. Personality and Individual Differences, 42(4), 665-675. https://doi.org/10.1016/j.paid.2006.08.0 16

Martarelli, C. S., \& Wolff, W. (2020). Too bored to bother? Boredom as a potential threat to the efficacy of pandemic containment measures Corinna.

Nabi, R. L. (2003). Exploring the framing effects of emotion: Do discrete emotions differentially influence information accessibility, information seeking, and policy preference? Communication Research, 30(2), 224-247. https://doi.org/10.1177/0093650202250 881

Nicholas, J. (2020). From social distancing to social containment: reimagining sociality for the coronavirus pandemic. In Medicine Anthropology Theory.

Öhman, A. (2008). Fear and Anxiety: Overlaps and Dissociations. In Handbook of Emotions (3rd ed.). https://doi.org/10.1007/978-3319-77619-4_2

Ornell, F., Schuch, J. B., Sordi, A. O., \& Kessler, F. H. P. (2020). "Pandemic fear" and COVID-19: mental health burden and strategies. Revista Brasileira de Psiquiatria (Sao Paulo, Brazil : 1999), 00(00), 10-13. https://doi.org/10.1590/1516-44462020-0008

Park, J. H., Faulkner, J., Schaller, M., Duncan, L., Ho, K., Messmer, R., \& Neuberg, S. (2003). Evolved disease-avoidance processes and contemporary anti-social behavior: prejudicial attitudes and avoidance of people with physical disabilities. Journal of Nonverbal Behavior, 27(2), 65-87. https://doi.org/10.1177/1368430204046
142

Pennycook, G., McPhetres, J., Zhang, Y., \& Rand, D. (2020). Fighting COVID-19 misinformation on social media: Experimental evidence for a scalable accuracy nudge intervention. PsyArXiv [Working Paper], 1-24. https://doi.org/10.31234/OSF.IO/UHBK9

Qi, Y., Du, C. D., Liu, T., Zhao, X., \& Dong, C. (2020). Experts' conservative judgment and containment of COVID-19 in early outbreak. Journal of Chinese Governance, 2346.

https://doi.org/10.1080/23812346.2020. 1741240

Raude, J., Debin, M., Souty, C., Guerrisi, C., Turbelin, C., Falchi, A., Bonmarin, I., Paolotti, D., Moreno, Y., Obi, C., Duggan, J., Wisniak, A., Flahault, A., Blanchon, T., \& Colizza, V. (2020). Are people excessively pessimistic about the risk of coronavirus infection? Center for Open Science, 5-10. https://doi.org/10.31234/osf.io/364qj

Raude, J., MCColl, K., Flamand, C., \& Apostolidis, T. (2019). Understanding health behaviour changes in response to outbreaks: Findings from a longitudinal study of a large epidemic of mosquito-borne disease. Social Science and Medicine, 230(February), 184193.

https://doi.org/10.1016/j.socscimed.2019 .04 .009

Roy, D., \& Sinha, K. (2020). Cognitive biases operating behind the rejection of government safety advisories during COVID19 Pandemic. January.

Rubin, G. J., Amlôt, R., Page, L., \& Wessely, S. (2009). Public perceptions, anxiety, and behaviour change in relation to the swine flu outbreak: Cross sectional telephone survey. BMJ (Online), 339(7713), 156. https://doi.org/10.1136/bmj.b2651

Schaller, M. (2006). Parasites, behavioral defenses, and the social psychological mechanisms through which cultures are evoked. Psychological Inquiry, 17(2), 96101.

https://doi.org/10.1207/s15327965pli17 02_2

Schaller, M., \& Duncan, L. A. (2007). The Behavioral Immune System: Its Evolution and Social Psychological Implications. In Evolution and the Social Mind.

Schaller, M., Park, J., \& Faulkner, J. (2003). Prehistoric dangers and contemporary prejudices. In European Review of Social Psychology (Vol. 14, Issue 1). https://doi.org/10.1080/1046328034000 0036

Slovic, P., \& Peters, E. (2006). Risk perception and 
affect. Current Directions in Psychological Science, 15(6), 322-325. https://doi.org/10.1111/j.14678721.2006.00461.x

Sznycer, D., \& Lukaszewski, A. W. (2019). The emotion-valuation constellation: Multiple emotions are governed by a common grammar of social valuation. Evolution and Human Behavior, 40(4), 395-404. https://doi.org/10.1016/j.evolhumbehav. 2019.05.002

Taleb, N. N., \& Norman, J. (2020). Ethics of Precaution: Individual and Systemic Risk.

Trumbo, C., Meyer, M. A., Marlatt, H., Peek, L., \& Morrissey, B. (2014). An Assessment of Change in Risk Perception and Optimistic
Bias for Hurricanes Among Gulf Coast Residents. Risk Analysis, 34(6), 1013-1024. https://doi.org/10.1111/risa.12149

Wu, B. P., \& Chang, L. (2012). The social impact of pathogen threat: How disease salience influences conformity. Personality and Individual Differences, 53(1), 50-54. https://doi.org/10.1016/j.paid.2012.02.0 23

Xie, W., Campbell, S., \& Zhang, W. (2020). Working memory capacity predicts individual differences in social distancing compliance during the COVID-19 pandemic in the US. PsyArXiv. https://doi.org/10.1073/pnas.200886811 7 